\title{
AXONAL TRANSPORT OF MUSCARINIC CHOLINERGIC RECEPTORS IN RAT VAGUS NERVE: HIGH AND LOW AFFINITY AGONIST RECEPTORS MOVE IN OPPOSITE DIRECTIONS AND DIFFER IN NUCLEOTIDE SENSITIVITY ${ }^{1}$
}

\author{
MARCO A. ZARBIN, JAMES K. WAMSLEY, ${ }^{2}$ AND MICHAEL J. KUHAR ${ }^{3}$ \\ Departments of Neuroscience, Pharmacology and Experimental Therapeutics, and Psychiatry and the Behavioral Sciences, \\ The Johns Hopkins University School of Medicine, Baltimore, Maryland 21205
}

Received October 26, 1981; Accepted February 5, 1982

\begin{abstract}
The presence and transport of muscarinic cholinergic binding sites have been detected in the rat vagus nerve. These binding sites accumulate both proximal and distal to ligatures in a timedependent manner. The results of double ligature and colchicine experiments are compatible with the notion that the anterogradely transported binding sites move by fast transport. Most of the sites accumulating proximal to ligatures bind the agonist carbachol with high affinity, while most of the sites accumulating distally bind carbachol with a low affinity. Also, the receptors transported in the anterograde direction are affected by a guanine nucleotide analogue (GppNHp), while those transported in the retrograde direction are less, or not, affected. The bulk of the sites along the unligated nerve trunk bind carbachol with a low affinity and are less sensitive to GppNHp modulation than the anterogradely transported sites. These results suggest that some receptors in the vagus may undergo axonal transport in association with regulatory proteins and that receptor molecules undergo changes in their binding and regulatory properties during their life cycle. These data also support the notion that the high and low affinity agonist forms of the muscarinic receptor represent different modulated forms of a single receptor molecule.
\end{abstract}

Many biochemical constituents of neurons undergo axonal flow and axoplasmic transport (for review, see Grafstein and Forman, 1980; Schwartz, 1979). Recently, it has been shown that receptors undergo axonal movement as well. Opiate and cholecystokinin receptors appear to undergo axonal flow in the rat vagus nerve (Young et al., 1980; Zarbin et al., 1981), and muscarinic cholinergic receptors have been reported to flow in the dog splenic nerve as well as in the rat sciatic nerve (Laduron, 1980; Wamsley et al., 1981b). In this commu-

\footnotetext{
' This work was supported by United States Public Health Service Grant MH25951, Research Career Development Type II Award MH000053 (M. J. K.), Medical Scientist Training Program Award GM07309 (M. A. Z.) and Public Health Service Grant NS15080 (J. K. W.). We gratefully acknowledge the clerical assistance of Ms. Darlene Weimer and Mrs. Mary Flutka and the technical assistance of Mrs. Theresa Kopajtic. We also thank Dr. N. J. M. Birdsall for detailed suggestions regarding the nucleotide experiments.

${ }^{2}$ Present address: Department of Psychiatry, College of Medicine, University of Utah, Salt Lake City, UT 84132.

${ }^{3}$ To whom correspondence should be addressed at Department of Neuroscience, Johns Hopkins University, 725 N. Wolfe Street, Baltimore, MD 21205.
}

nication, we report that muscarinic cholinergic receptors undergo axonal flow in the rat vagus nerve. The characteristics of the flow and the receptors involved have been examined in some detail. Receptors were assayed by light microscopic autoradiography which provides a high degree of resolution and sensitivity.

\section{Materials and Methods}

Tissue preparation. Male rats (150 to $250 \mathrm{gm}$; SpragueDawley, Madison, WI) were anesthetized with pentobarbital $(65 \mathrm{mg} / \mathrm{kg}$, i.p.). The right cervical vagus then was surgically exposed. The nerve trunk was dissected away from surrounding blood vessels and connective tissue, and the nerve was ligated (size 4-0 silk, nonabsorbable, surgical suture) about $1.5 \mathrm{~cm}$ distal to the nodose ganglion. When consecutive ligatures were placed on the nerve trunk, they were separated by approximately 15 $\mathrm{mm}$. When injections were made into the nerve trunk, the ligature was first placed around the nerve, and the material was subsequently injected approximately $2 \mathrm{~mm}$ proximal to the ligature using a Hamilton $10-\mu$ l syringe. The animal was allowed to recover postoperatively. After the appropriate interval of ligation, the ligated nerve was 
removed surgically (under anesthesia). Three to $4 \mathrm{~mm}$ of tissue on each side of the ligature was retained. The nerve was mounted immediately in brain paste (homogenized brain tissue) on a microtome chuck and frozen in liquid nitrogen.

Autoradiographic experiments. Autoradiograms were generated by the procedure outlined by Young and $\mathrm{Ku}$ har (1979). Briefly, longitudinal 8- $\mu \mathrm{m}$-thick frozen sections of vagus nerve were cut on a Harris cryostat microtome (Harris Manufacturing Co., North Billerica, MA). The sections were thaw-mounted onto subbed glass microscope slides and stored at $-20^{\circ} \mathrm{C}$. Muscarinic cholinergic receptors were labeled by incubating slide-mounted tissue sections with either $1 \mathrm{nM}\left[{ }^{3} \mathrm{H}\right]$ quinuclidinyl benzylate (QNB; $40 \mathrm{Ci} / \mathrm{mmol}$; Amersham, Inc.) or $1 \mathrm{nM} N$. $\left[{ }^{3} \mathrm{H}\right]$ methyl scopolamine (NMS; $50 \mathrm{Ci} / \mathrm{mmol}$; New England Nuclear). The experimental conditions appropriate for labeling muscarinic receptors with a high degree of pharmacological specificity and optimal specific to nonspecific binding ratios have been described elsewhere in detail (Wamsley et al., 1980, 1981a). Following the protocol outlined in those studies, tissue sections were incubated in phosphate-buffered saline (containing NMS or QNB) for 1 (NMS) or $2(\mathrm{QNB}) \mathrm{hr}$ at $23^{\circ} \mathrm{C}$ and subsequently were washed in buffer for 10 min at $4^{\circ} \mathrm{C}$. Nonspecific binding was determined by incubating some tissue sections in the presence of $1 \mu \mathrm{M}$ atropine sulfate. In displacement or saturation experiments, consecutive tissue sections were incubated in various concentrations of NMS or NMS plus displacer. After the wash, the slides were dried and apposed against glass coverslips which had been dipped in photographic emulsion previously (Kodak, NTB-3) and allowed to dry. The emulsion was developed after 4 to 6 weeks exposure.

Quantitation of data. Autoradiograms were viewed using an Olympus microscope (Olympus Optical, Japan), and the data were quantified (by recording grain density), using a Zeiss Universal microscope (Zeiss, Federal Republic of Germany) and an eyepiece equipped with a superimposed grid. Previous studies (Young and Kuhar, 1979; Unnerstall et al., 1981) have shown that this autoradiographic technique is quantitative (grain density proportional to time of exposure and tissue content of radioactivity). Typically, nonspecific binding was less than $10 \%$ of total binding. Specific binding is shown in Figures 1 to 5 .

Radioactive standards (tissue sections containing a known concentration of radioactivity) were included in some experiments. Using the standards, a standard curve relating grain density to radioactivity concentration (disintegrations per min per $\mathrm{mg}$ of tissue, wet weight) was generated. From this curve, the concentration of receptors in the nerve segment (femtomoles per $\mathrm{mg}$ of tissue, wet weight) was calculated.

\section{Results}

Time course of receptor accumulation. Ligatures were placed around rat vagi and allowed to remain in place for various times between 0 and $24 \mathrm{hr}$. After the appropriate time of ligation, the nerve trunk was removed and processed for autoradiography as described under "Materials and Methods." The slide-mounted vagal tissue sections were labeled with $1 \mathrm{nM}\left[{ }^{3} \mathrm{H}\right] \mathrm{QNB}$. Examples of autoradiographs showing the transport of receptors have been published previously (Young et al., 1980; Zarbin et al., 1981). The quantified results of these experiments are shown in Figure 1. An accumulation of muscarinic cholinergic binding sites was observed both proximal and distal to the ligature. The buildup was greater in magnitude proximal to the ligature. This accumulation of binding sites was time dependent. Proximal to the ligature, the accumulation was linear with time over the first 24 hr of ligation (i.e., the buildup of grains occurred at a constant rate). No accumulation of binding sites was detected at $0 \mathrm{hr}$ of ligation. The accumulation of sites distal to the ligature occurred in a linear fashion during the first $12 \mathrm{hr}$ of ligation. The rate of distal accumulation appeared to decrease between 12 and $24 \mathrm{hr}$ of ligation. Binding in the presence of $1 \mu \mathrm{M}$ atropine was negligible at all points along the nerve trunk (not shown).

Pharmacologic experiments. The ability of atropine to displace $\left[{ }^{3} \mathrm{H}\right] \mathrm{QNB}$ binding suggests that the transported binding sites have the pharmacologic characteristics of muscarinic receptors assayed in membrane homogenates. To investigate the pharmacology of the transported sites further, saturation experiments were carried out using $\left[{ }^{3} \mathrm{H}\right] \mathrm{NMS}$. Consecutive vagal tissue sections were incubated in either $0.2,0.5,1$, or $2 \mathrm{M}\left[{ }^{3} \mathrm{H}\right] \mathrm{NMS}$. At each concentration of $\left[{ }^{3} \mathrm{H}\right] \mathrm{NMS}$, some slides were coincubated with $1 \mu \mathrm{M}$ atropine to generate blanks. The tissue then was processed for autoradiography. Since the

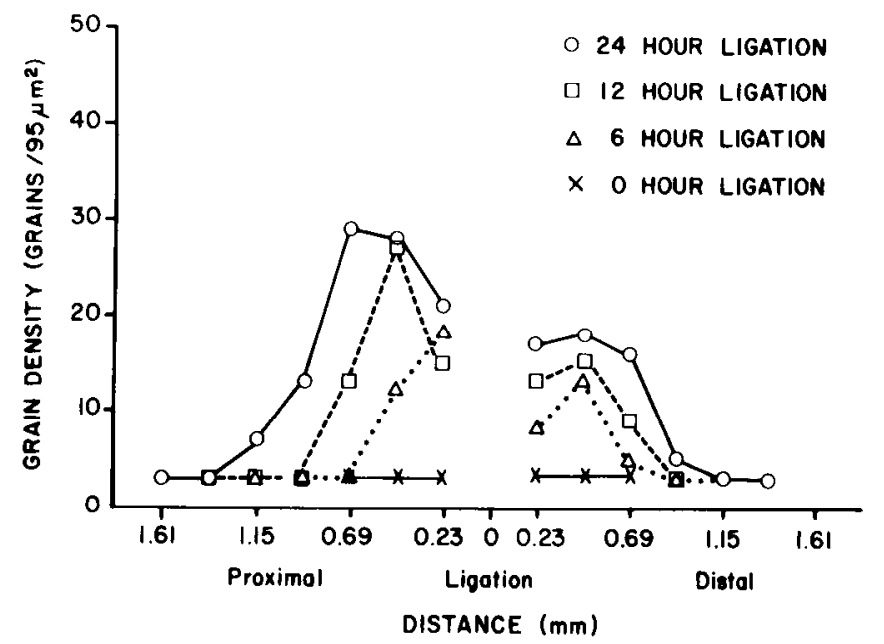

Figure 1. Time course of muscarinic cholinergic binding site accumulation. Vagal nerve trunks were ligated for various times between 0 and $24 \mathrm{hr}$. The tissue then was used to generate autoradiograms as described under "Materials and Methods." One nanomolar $\left[{ }^{3} \mathrm{H}\right] \mathrm{QNB}$ was used to label the binding sites. Proximal indicates $x$ coordinates proximal to the point of ligation. The $x$ coordinate 0 is assigned to the point at which the ligature was placed. This experiment was repeated in 24 animals (6/time point) with essentially identical results. Data from a typical experiment are shown. The total grain density at each point is the average of five determinations which differed by less than $15 \%$. The exposure time was 5 weeks. The relative accumulations (defined as the ratio of the accumulation of grains above "base line" levels after a given ligation time to the accumulation of grains after $6 \mathrm{hr}$ of ligation) proximal to the ligature are: $0 \mathrm{hr}, 0 ; 6 \mathrm{hr}, 1.0 ; 12 \mathrm{hr}, 2.0$; and $24 \mathrm{hr}, 3.7$; and the relative accumulations distal to the ligature are: $0 \mathrm{hr}, 0 ; 6 \mathrm{hr}$, $1.0 ; 12 \mathrm{hr}, 1.7$; and $24 \mathrm{hr}, 2.3$. 


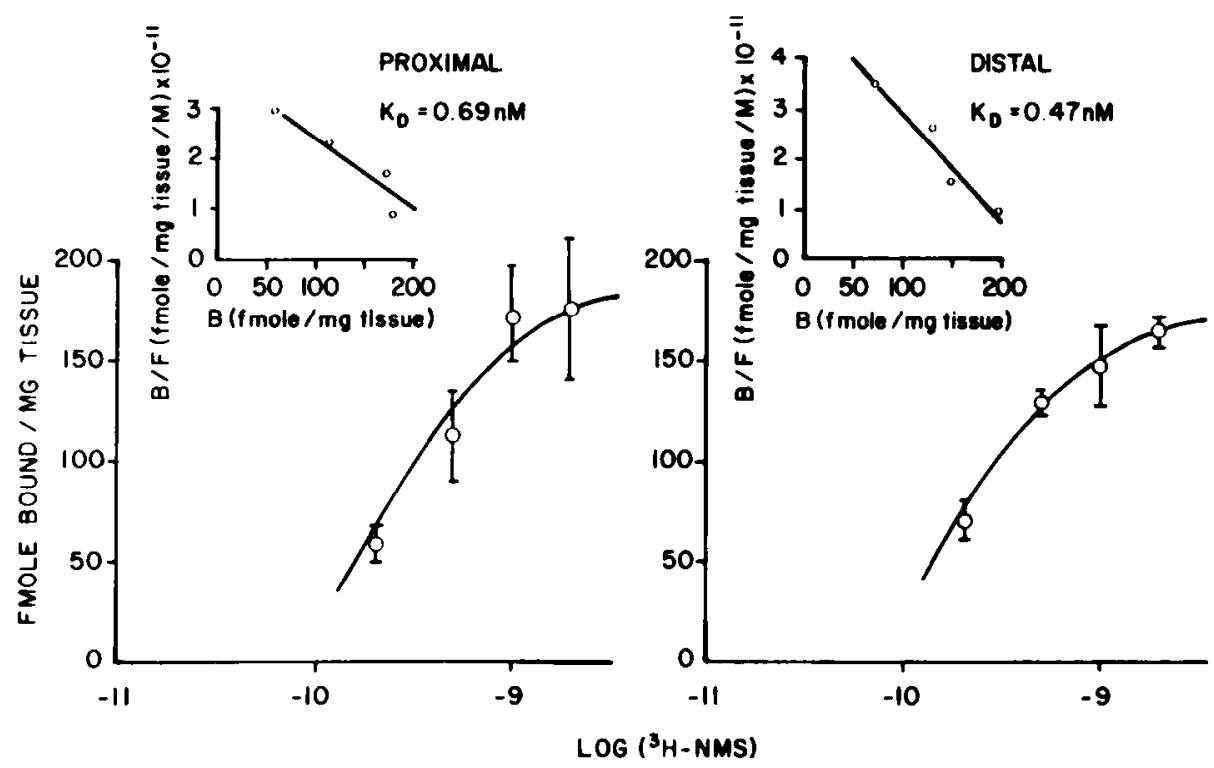

Figure 2. Saturation analysis of transported muscarinic binding sites. Tissue sections of vagal nerve trunks which had been ligated for $22 \mathrm{hr}$ were used to generate autoradiograms. Data are reported as the mean \pm SEM $(n=$ at each point $)$. Proximal and distal refer to the analysis of the regions $0.23 \mathrm{~mm}$ proximal and distal to the ligature, respectively. These areas were examined since areas near the ligature should be enriched in transported binding sites. The exposure time was 6 weeks. $B / F$, Bound/free.

area of the nerve trunk immediately adjacent to the ligature (i.e., $0.23 \mathrm{~mm}$ proximal or distal to the ligature) is enriched in transported binding sites, $\left[{ }^{3} \mathrm{H}\right] \mathrm{NMS}$ binding was quantified $0.23 \mathrm{~mm}$ proximal and $0.23 \mathrm{~mm}$ distal to the point of ligation (Fig. 2). Scatchard analysis of the saturation data indicates apparent dissociation constants of 0.69 and $0.47 \mathrm{nM}$ for the sites accumulating proximal and distal to the ligature, respectively. These values are very similar to those reported by Berric et al. (1979) for muscarinic receptors assayed in homogenates of rat cardiac tissue and are somewhat higher than that in brain.

To investigate the pharmacologic characteristics of the transported binding sites further, the ability of levallorphan and carbachol to displace $\left[{ }^{3} \mathrm{H}\right] \mathrm{NMS}$ binding was analyzed (Table I). While $10^{-2} \mathrm{M}$ carbachol, a cholinergic agonist, is able to displace essentially all of the $\left[{ }^{3} \mathrm{H}\right] \mathrm{NMS}$ binding, $10^{-6} \mathrm{M}$ levallorphan, an opiate antagonist, is minimally effective as a displacer. Thus, the transported binding sites appear to have the pharmacologic characteristics of muscarinic cholinergic receptors.

Effect of consecutive ligatures on muscarinic receptor transport. To investigate the possibility that receptor transport could continue when the axon is separated from the cell body, consecutive ligatures were placed on the vagal nerve trunk and were allowed to remain in place for $24 \mathrm{hr}$. After this time, the tissue was removed and processed for autoradiography as described under "Materials and Methods" (Fig. 3). An accumulation of receptors was observed proximal to both ligatures. The accumulation proximal to the distal ligature (i.e., that furthest from the nodose ganglion) was smaller in magnitude (about $50 \%$ ) than that at the other ligature. The gradient of the buildup at the distal ligature appeared to be similar to that at the proximal ligature. Only a negligible accumulation of receptors was detected distal to
TABLE I

Pharmacology of transported muscarinic binding sites Consecutive slide-mounted tissue sections (longitudinal) of ligated (24-hr) rat vagi were incubated in the presence of either $1 \mathrm{nM}\left[{ }^{3} \mathrm{H}\right] \mathrm{NMS}$ or 1 nм $\left[{ }^{3} \mathrm{H}\right] \mathrm{NMS}$ plus the noted concentration of displacer. The data were quantified as described under "Materials and Methods" and are reported as the mean \pm SEM. "Percent of Total Bound" refers to the fraction of total binding present at a point $0.23 \mathrm{~mm}$ proximal to the ligature. This area has been examined because points near the ligature are enriched in transported binding sites.

\begin{tabular}{lcc}
\hline \multicolumn{1}{c}{ Displacer } & [Displacer] & Percent Total Bound $(n)$ \\
\hline & $M$ & \\
Atropine & $10^{-6}$ & $2 \pm 1(6)$ \\
Carbachol & $10^{-2}$ & $7 \pm 2(6)$ \\
Levallorphan & $10^{-6}$ & 88,96 \\
\hline
\end{tabular}

the proximal ligature. Distal to the distal ligature, however, an accumulation of receptors was observed. At no point between the ligatures did the binding site density decrease to background levels. Thus, only a small fraction of the axonal binding sites appears to be moving.

Effect of colchicine on muscarinic receptor transport. Colchicine is an alkaloid which, in low doses, may block fast transport relatively selectively (McClure, 1972). To test the effect of this compound on muscarinic receptor transport, $5 \mu \mathrm{l}$ of $100 \mu \mathrm{M}$ colchicine (dissolved in $0.9 \%$ $\mathrm{NaCl}$ ) was injected into the nerve trunk on the proximal side of the vagal ligatures. Vehicle injections were used as controls. After $20 \mathrm{hr}$ of ligation, the tissue was removed and processed for autoradiography (Fig. 4). It can be seen that the accumulation of receptors, proximal but not distal to the ligature, in colchicine-treated nerves is much less than that in vehicle-injected nerves. Proximal to the injection site, a diffuse buildup of grains was observed (data not shown). 


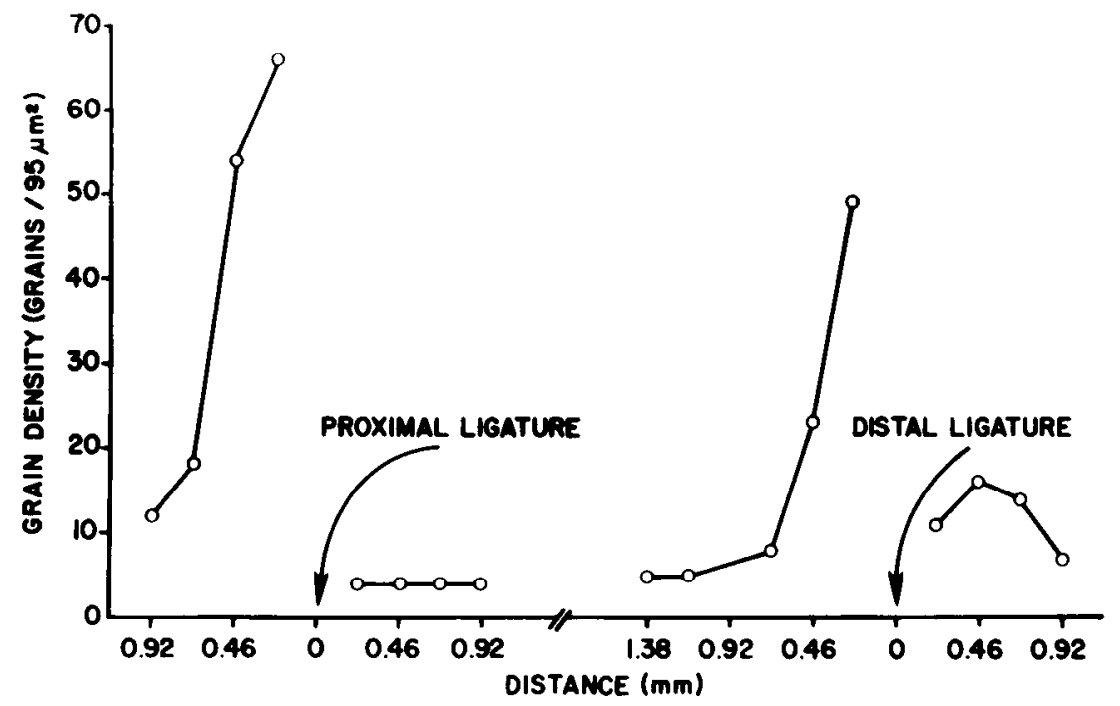

Figure 3. Double ligature experiment. One nanomolar $\left[{ }^{3} \mathrm{H}\right] \mathrm{NMS}$ was used to label the binding sites. The proximal ligature is the one closest to the nodose ganglion. This experiment was replicated in 3 animals with similar results. Data from a typical experiment are shown. See the legend to Figure 1 for quantification of data. The exposure time was 6 weeks.

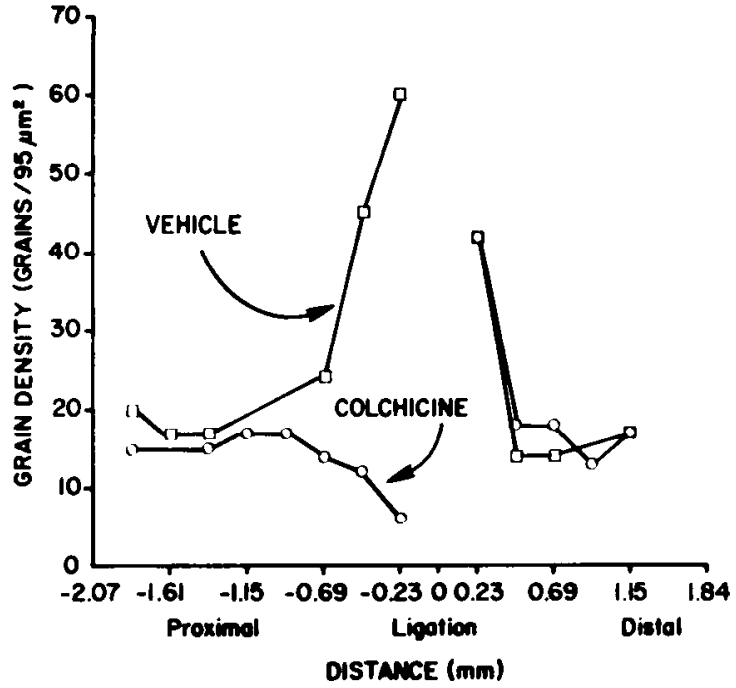

Figure 4. Effect of colchicine on muscarinic binding site transport. Negative $x$ coordinates represent areas proximal to the ligature, while positive $x$ coordinates represent areas distal to the ligature. The binding sites were labeled with $1 \mathrm{nM}\left[{ }^{3} \mathrm{H}\right]$ NMS. The experiment was repeated in 3 animals with similar results. Data from a typical experiment are shown. The exposure time was 6 weeks. See the text for details.

High versus low affinity muscarinic receptor transport. It has been shown that muscarinic cholinergic agonists bind to three receptor sites in brain, each distinguished by its affinity for the agonists. Antagonists, on the other hand, bind to each of these sites with an equal, high affinity (Birdsall et al., 1978b; Hulme et al., 1978). Thus, it has been possible to localize autoradiographically the high and the low affinity binding sites in the rat brain by incubating some tissue sections with $1 \mathrm{nM}\left[{ }^{3} \mathrm{H}\right]$ NMS (to label both the high and low affinity muscarinic receptors) and incubating consecutive sections in $1 \mathrm{nM}$ $\left[{ }^{3} \mathrm{H}\right] \mathrm{NMS}$ plus $10^{-4} \mathrm{M}$ carbachol (a concentration of car- bachol which will displace $\left[{ }^{3} \mathrm{H}\right] \mathrm{NMS}$ binding preferentially from high affinity sites (Wamsley et al., 1980)). To investigate the transport of high and low affinity binding sites in the rat vagus nerve, some tissue sections were incubated with $2 \mathrm{nM}\left[{ }^{3} \mathrm{H}\right] \mathrm{NMS}$ while consecutive sections were incubated with $2 \mathrm{nM}\left[{ }^{3} \mathrm{H}\right] \mathrm{NMS}$ plus $10^{-4} \mathrm{M}$ carbachol or $2 \mathrm{nM}\left[{ }^{3} \mathrm{H}\right] \mathrm{NMS}$ plus $1 \mu \mathrm{M}$ atropine (Fig. 5 ). It can be seen that, while $10^{-4} \mathrm{M}$ carbachol displaces much (56\%) of the NMS binding proximal to the ligature, much less NMS binding $(25 \%)$ is displaced distal to the ligature. Similar results were obtained when the nerves were ligated for 6,12 , or $24 \mathrm{hr}$ (data not shown).

To investigate this phenomenon further, consecutive tissue sections were incubated with $2 \mathrm{nM}\left[{ }^{3} \mathrm{H}\right] \mathrm{NMS}$ in the presence of varying concentrations of carbachol (Fig. 6). It can be seen that, immediately proximal to the point of ligation, carbachol has an $\mathrm{IC}_{50}$ of $9 \times 10^{-8} \mathrm{M}$, while, distally, it has an $\mathrm{IC}_{50}$ of $1.3 \times 10^{-4} \mathrm{M}$. This result suggests that the bulk of the binding sites accumulating proximal to the ligature are high affinity agonist binding sites, while most of the sites accumulating distally are low affinity sites. Moreover, at points far removed from the ligature, carbachol binds both proximally and distally with an $\mathrm{IC}_{50}$ of $\simeq 10^{-4} \mathrm{M}$ (Fig. 6).

Effect of guanyl-5'-yl imidodiphosphate (GppNHp) on receptor binding. GppNHp, a nonmetabolizable analogue of GTP, has been shown to inhibit the binding of the agonist carbachol to myocardial muscarinic cholinergic receptors by decreasing agonist affinity (Berrie et al., 1979; Wei and Sulakhe, 1979; Rosenberger et al., 1979, 1980). The binding of the antagonist NMS is essentially unaffected by the nucleotide. Accordingly, the effect of GppNHp on agonist binding to the tranported receptor was investigated. Consecutive rat vagal tissue sections were incubated in the presence of $1 \mathrm{nM}\left[{ }^{3} \mathrm{H}\right] \mathrm{NMS}, 1 \mathrm{nM}$ $\left[{ }^{3} \mathrm{H}\right] \mathrm{NMS}$ plus $10^{-4}$ м carbachol, or $1 \mathrm{~nm}\left[{ }^{3} \mathrm{H}\right] \mathrm{NMS}$ plus $10^{-4}$ м carbachol plus $10^{-5}$ м GppNHp. The incubation conditions were those described under "Materials and 


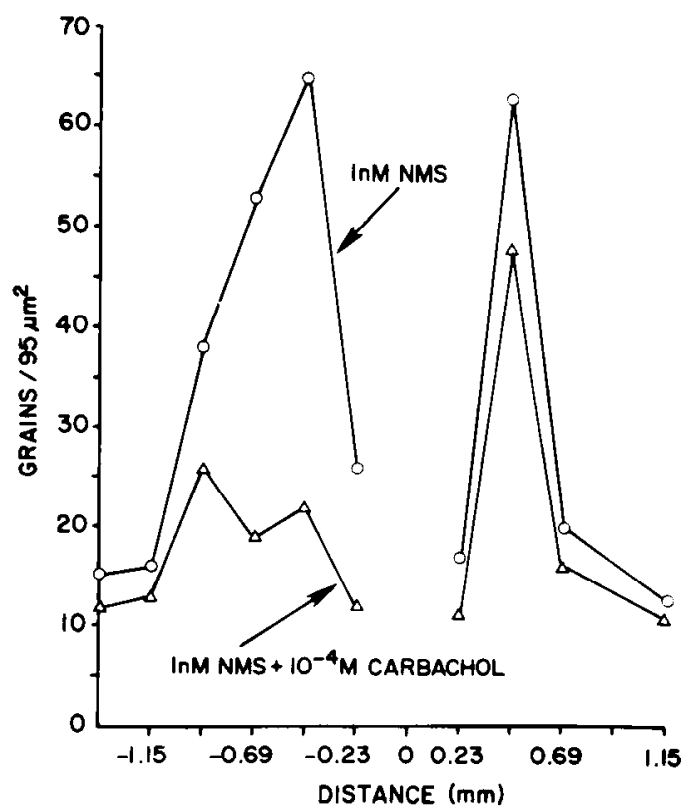

Figure 5. Effect of carbachol on $\left[{ }^{3} \mathrm{H}\right] \mathrm{NMS}$ binding to ligated vagus nerve. Tissue sections of nerves ligated for $22 \mathrm{hr}$ were used for assay. This experiment has been replicated 10 times with similar results. Data from a typical experiment are shown. The exposure time was 6 weeks. See the text for details.

Methods" except that $10 \mathrm{~mm} \mathrm{MgCl}_{2}$ was added to the incubation medium. The rationale of this design is as follows. If $\mathrm{GppNHp}$ reduces carbachol binding to the transported site, then $\left[{ }^{3} \mathrm{H}\right] \mathrm{NMS}$ binding in the presence of $10^{-4} \mathrm{M}$ carbachol should be increased when GppNHp is added to the incubation medium. The results of this experiment (Table II) indicate that GppNHp markedly decreased the potency of carbachol at the sites accumulating proximal to vagal ligatures since the binding of $\left[{ }^{3} \mathrm{H}\right] \mathrm{NMS}$ increased from $27 \%$ of control in the presence of carbachol to $86 \%$ of control when GppNHp and carbachol were co-incubated. Similarly, the binding of carbachol to sites far removed from the ligature appeared to be inhibited by GppNHp but less so. The binding of carbachol to the distally accumulating sites, on the other hand, seemed less sensitive to inhibition by GTP than either the proximally accumulating sites or the sites far removed from the ligature.

\section{Discussion}

The transport of opiate (Young et al., 1980) and cholecystokinin (Zarbin et al., 1981) receptors has been detected recently in the rat vagus nerve. Muscarinic cholinergic receptor transport has been observed in the dog splenic nerve (Laduron, 1980) and in the rat sciatic nerve (Wamsley et al., 1980b) as well. In this communication, properties of the transported muscarinic binding sites in the vagus nerve are described.

The axonal localization of muscarinic receptors is compatible with the view that these receptors are presynaptic and, given the cholinergic nature of parasympathetic nerves, possibly autoreceptors as well. Presynaptic cholinergic receptors have been detected in other systems. For example, axonal cholinergic receptors which appear to be nicotinic have been described biochemically (Jones

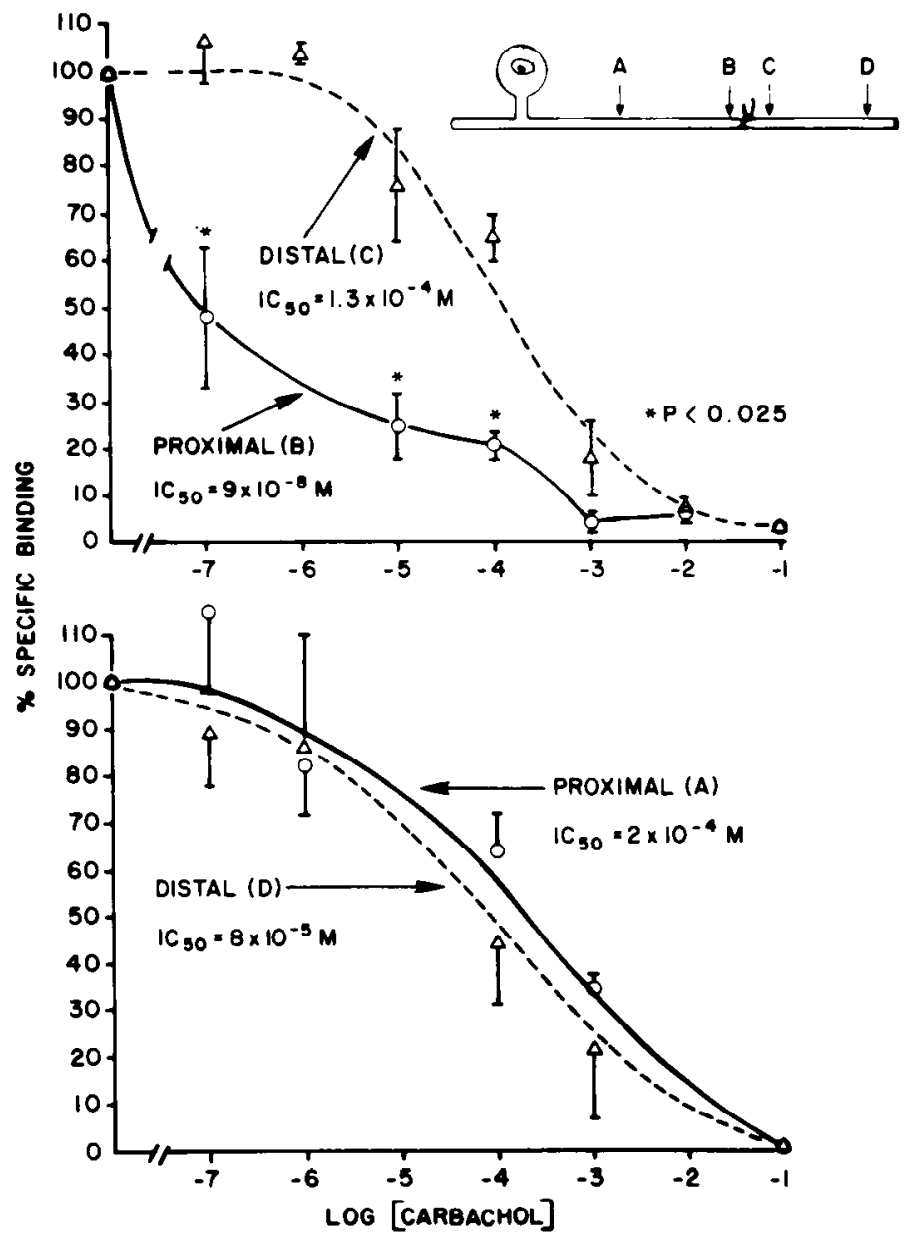

Figure 6. Carbachol displacement of $\left[{ }^{3} \mathrm{H}\right] \mathrm{NMS}$ binding to ligated rat vagi. Tissue sections of nerves ligated for $22 \mathrm{hr}$ were used for assay. Consecutive tissue sections were incubated in 2 nM $\left[{ }^{3} \mathrm{H}\right] \mathrm{NMS}$ plus varying concentrations (units of moles per liter) of carbachol. Binding was assayed at points close to the ligature $(B$ and $C$ ) to investigate areas enriched in transported receptors, while areas far removed from the ligature $(A$ and $D$ ) were analyzed to investigate areas enriched in axonal (i.e., nonmobile) receptors. Data are reported as the mean \pm SEM $(n=3)$. The binding at $10^{-1} \mathrm{M}$ carbachol is the mean of two determinations which differed by less than $10 \%$. The points marked with an asterisk differ significantly ( $p<0.025$; Student's unpaired $t$ test) from corresponding unmarked points. See the text for details.

et al., 1977) and electrophysiologically (Hancock and Volle, 1969; Armett and Ritchie, 1961). The existence of functional presynaptic muscarinic receptors on noradrenergic (for reviews, see Westphall, 1977; Starke, 1977; Langer, 1977) and cholinergic (Szerb et al., 1977) nerve terminals is well known.

The results of this study are compatible with the possibility that muscarinic receptors move by fast transport (versus slow transport). The translocation of substances by slow transport appears to require continuity between the cell body and the axon, while fast transport may occur even in isolated axons (see Schwartz, 1979; Grafstein and Forman, 1980, for review). Isolation of the axon from the cell body can be accomplished in vivo by placing two consecutive ligatures around the nerve trunk. 
TABLE II

Effect of GppNHp on carbachol inhibition of $\left[^{3} \mathrm{H}\right] N M S$ binding to ligated rat vagi

Consecutive tissue sections of rat vagi (ligated for $22 \mathrm{hr}$ ) were incubated in either $1 \mathrm{nM}\left[{ }^{3} \mathrm{H}\right] \mathrm{NMS}$ plus $10^{-4}$ M carbachol or $1 \mathrm{nM}\left[{ }^{3} \mathrm{H}\right]$ NMS plus $10^{-4} \mathrm{M}$ carbachol plus $10^{-5} \mathrm{M}$ GppNHp as described under "Materials and Methods." Ten millimolar $\mathrm{MgCl}_{2}$ was added to the incubation medium as Berrie et al. (1979) have shown that $\mathrm{MgCl}_{2}$ is required for the inhibition of carbachol binding to rat muscarinic receptors. Autoradiograms were subsequently developed and quantified. Total binding proximal $(0.23 \mathrm{~mm})$, distal $(0.23 \mathrm{~mm})$, and far removed $(1.15 \mathrm{~mm})$ from the ligature proximally was $175 \pm 12(n=4)$, $146 \pm 15(n=3)$, and $5.5 \pm 0.92(n=5) \mathrm{fmol} / \mathrm{mg}$ of tissue, dry weight, respectively.

\begin{tabular}{lcc}
\hline $\begin{array}{c}\text { Location along } \\
\text { Ligated Nerve Trunk }\end{array}$ & $10^{-4} \mathrm{M}$ Carbachol & $\begin{array}{c}10^{-5} \mathrm{M} \text { GppNHp }+ \\
10^{-4} \mathrm{M} \text { Carbachol }\end{array}$ \\
\hline Proximal $(0.23 \mathrm{~mm})$ & $27 \pm 6(4)^{a}$ & $81 \pm 9^{b}(4)$ \\
Distal $(0.23 \mathrm{~mm})$ & $75 \pm 3(3)$ & $83 \pm 7^{c}(3)$ \\
Proximal $(1.15 \mathrm{~mm})$ & $61 \pm 11(4)$ & $83 \pm 16^{d}(4)$ \\
\hline
\end{tabular}

${ }^{\prime \prime}$ Data are the mean $\pm \mathrm{SEM}$; the percentage of total binding is given in parentheses.

${ }^{h}$ Different from carbachol incubation with $p<0.005$ (paired $t$ tests).

"Different from carbachol incubation with $p<0.1$ (paired $t$ test), not significantly different.

"Different from carbachol incubation with $p<0.05$ (paired $t$ test).

The accumulation of binding sites proximal to the distal ligature thus suggests that the transport apparatus is locally present and functional along the axon. Thus, muscarinic receptors probably move by fast transport. The accumulation of receptors distal to the proximal ligature was negligible although a significant accumulation was detected distal to the distal ligature. This result suggests that the distal accumulation of binding sites is due to retrograde transport. The failure to observe an accumulation of binding sites distal to the proximal ligature is somewhat surprising. Since the isolated nerve trunk was able to support a significant amount of anterograde transport, one would expect the retrogradely moving material to be detectable at the proximal ligature, albeit in smaller quantities. The lack of a detectable retrograde accumulation at the proximal ligature actually might mean that retrograde transport was impaired in the isolated segment. On the other hand, we cannot rule out the possibility that the accumulation was not detected due to technical reasons or due to the rather long ligation times used. Colchicine, in low doses, may impair fast transport relatively selectively (McClure, 1972). The data of Figure 4 show that muscarinic receptor transport is inhibited by cholchicine. The unimpaired buildup of receptors distally corroborates the localization of transport disruption to the site of colchicine injection.

Muscarinic receptors accumulate at ligatures in a timedependent manner during the first $24 \mathrm{hr}$ of ligation. The linear nature of the time dependence (i.e., constant rate) also has been observed for vagal opiate (Young et al., 1980) and cholecystokinin (Zarbin et al., 1981) receptors. The decreased rate of retrograde accumulation after 12 $\mathrm{hr}$ of ligation is probably secondary to the degeneration of the distal nerve stump which is significant after $18 \mathrm{hr}$ of ligation (Grafstein and McQuarrie, 1978). The rate of receptor movement can be estimated by dividing the total accumulation in $24 \mathrm{hr}$ by the average receptor density in an unligated 1-mm segment of the nerve trunk. According to this analysis, the estimated rate of transport proximal to the ligature is $8.3 \pm 0.35 \mathrm{~mm} /$ day (mean \pm SEM; $n=4$ ), and the rate of transport distal to the ligature (during the first $14 \mathrm{hr}$ of ligation) is $4.9 \pm 0.4$ $\mathrm{mm} /$ day $(n=3)$. These values are similar in magnitude to the estimated transport rates of vagal opiate and cholecystokinin receptors. As pointed out elsewhere (Zarbin et al., 1981), however, it is likely that these calculations underestimate the true rate since the analysis is based on the assumption that $100 \%$ of the receptors present in the nerve are undergoing transport. The double ligature experiments show that the receptor densities in between the ligatures are not depleted significantly. Thus, only a small fraction of the receptors present in the nerve appears to be moving. Brimijoin and Wiermaa (1978) have shown that, in the case of acetylcholinesterase, only about $10 \%$ of the protein undergoes transport.

The calculated rate of anterograde muscarinic receptor accumulation is 1.7 times greater than the calculated rate of retrograde accumulation. Grafstein and Forman (1980) have pointed out that the rate of anterograde transport is often about 2 times greater than the rate of retrograde transport. The data of this study thus appear to be in agreement with their generalization. This difference in transport rates could explain why the accumulation of receptors proximal to the ligature is consistently greater than the distal accumulation.

The cholinergic binding sites assayed in this study appear to have the pharmacologic characteristics of muscarinic cholinergic receptors. Our results are in agreement with those from rat brain homogenate studies (Yamamura and Snyder, 1974). Also, Laduron (1980) has shown that transported muscarinic binding sites in the dog splenic nerve have the pharmacologic characteristics of muscarinic receptors.

Biochemical kinetic examination of muscarinic cholinergic receptors has revealed that more than one type of receptor exists and that there are possibly three different receptors distinguished by differing affinities for agonists (Birdsall et al., 1978a, b; Hulme et al., 1978). Antagonist drugs recognize these different receptors with about the same equal high affinity. Carbachol displacement experiments indicate that the population of muscarinic receptors accumulating proximal to ligatures (referred to as $\mathrm{P}$ receptors) differs from the population accumulating distal to ligatures (referred to as D receptors). Specifically, the former receptors bind carbachol with a high affinity $\left(\mathrm{IC}_{50}\right.$ of $\left.9 \times 10^{-8} \mathrm{M}\right)$, while the latter bind carbachol with a low affinity $\left(\mathrm{IC}_{50}\right.$ of $\left.1.3 \times 10^{-4} \mathrm{M}\right)$. Using the ChengPrusoff equation (Cheng and Prusoff, 1973), these $\mathrm{IC}_{50}$ values can be converted to $K_{i}$ values. Assuming the apparent dissociation constant $\left(K_{d}\right)$ of NMS to be $0.6 \mathrm{nM}$ for the binding sites, the $\mathrm{P}$ receptors exhibit a $K_{i}$ of $2 \times$ $10^{-8} \mathrm{M}$ for carbachol, while the $\mathrm{D}$ receptors exhibit a $K_{i}$ of $3 \times 10^{-5}$ M. Birdsall et al. (1978b) have shown that carbachol binds to the high affinity muscarinic receptor with a $K_{d}$ of $5 \times 10^{-7} \mathrm{M}$ and to the low affinity receptor with a $K_{d}$ of $9 \times 10^{-5} \mathrm{M}$. Thus, the $\mathrm{P}$ receptors and the D receptors appear to be similar to the high and the low affinity agonist receptors, respectively, of Birdsall et al. (1978b). The $K_{i}$ of the $\mathrm{P}$ receptors appears to be somewhat smaller in magnitude than the $K_{d}$ of the high 
affinity receptors. The difference may simply be due to the crudeness of the analysis employed to determine the $K_{i}$ (the $\mathrm{IC}_{50}$ values were interpolated from the data of Fig. 6). On the other hand, it may be that the so-called "super high" affinity receptors (Birdsall et al., 1978b), which normally constitute a small percentage of the population, are present in significant numbers proximal to the point of ligation. The axonal receptors present at points far removed ( $\geq 1 \mathrm{~mm}$ ) from the ligature proximally and distally exhibit $K_{i}$ values of $5 \times 10^{-5} \mathrm{M}$ and $2 \times 10^{-5}$ $M$, respectively, for carbachol. Thus, these receptors, which are most of the axonal receptors, appear similar to low affinity agonist receptors. The finding that the bulk of the axonal receptors are low affinity agonist sites while the anterogradely transported receptors are high affinity agonist sites (i.e., those accumulating at the ligature) also suggests that only a small fraction of the axonal receptors is moving.

Several explanations may account for the observed difference between $P$ and $D$ receptors. One possibility is that the difference is an artifact of ligation. This seems unlikely since double ligation of the vagus nerve trunk results in the accumulation of $P$ receptors and $D$ receptors at the distal ligature, but only $\mathrm{P}$ receptors appear to accumulate at the proximal ligature. Thus, ligation alone probably cannot induce the presence of two different populations of muscarinic receptors.

Another possibility is that the soma exports a heterogeneous population of receptors, but differences in the mobility of high (i.e., P) and low (i.e., D) affinity receptors result in their selective accumulation proximal and distal to ligatures, respectively. Proximal to the ligature for example, low affinity receptors may undergo a "turn around" in transport direction (Bisby and Bulger, 1977) more easily than high affinity receptors with the result that high affinity sites accumulate proximal to ligatures. A corollary of this proposition is that low and high affinity receptors differ in some respect with regard to their mechanism of anterograde transport. While this possibility cannot be refuted at present, it seems unlikely.

Another explanation is that the bulk of the receptors exported from their soma of origin exist primarily in the high affinity state, while most of those returning to the cell body exist mainly in the low affinity state. The anterogradely transported receptor population may undergo an alteration in its binding properties with insertion in the membrane at the synaptic terminal or along the axon. The low affinity state may be maintained as the membrane is recycled by retrograde transport. This explanation, which we favor, can account for the accumulation of high affinity sites proximal to ligatures and low affinity site accumulation distal to ligatures and is consistent with the results of the double ligature experiment as well. A potential difficulty with this hypothesis is that the transported receptor populations may not be homogeneous. The data of Figure 6 suggest that the carbachol displacement curves have a Hill coefficient less than 1 (especially in the case of the $\mathrm{P}$ receptors). Homogeneous receptor populations generally exhibit Hill coefficients of 1 in such studies. Thus, the two populations of transported binding sites appear to have some degree of heterogeneity, albeit slight. The muscarinic receptors present in the unligated nerve trunk also ap- pear to be heterogeneous, as judged by this criterion. Nonetheless, most of these nontransported sites seem to be of the low affinity type.

The results of the GppNHp experiments indicate that the anterogradely transported binding site is sensitive to regulation by guanine nucleotides. As the bulk of the anterogradely transported receptors appear to be of the high affinity type, these data indicate that the high affinity agonist binding site may be sensitive to regulation by guanine nucleotides in agreement with the results of Wei and Sulakhe (1979) and Rosenberger et al. (1980). In other words, the anterograde transported binding sites are capable of heing converted from a high to a low affinity agonist binding state by GppNHp. This implies the existence of a functional association between the anterogradely transported binding site and a regulatory moiety, such as the nucleotide regulatory protein (Berrie et al., 1979; Rodbell, 1980; Lefkowitz and Williams, 1978). The retrogradely transported site, on the other hand, appears to be in a low affinity state and insensitive to GTP. This might be due to the presence of a very tightly bound endogenous nucleotide, to an inability of the retrogradely transported receptor to be coupled to a regulatory moiety, or to a lack of functional regulatory moiety distal to the ligature. A large body of evidence suggests that $\beta$-adrenergic receptors bind agonist with low affinity when uncoupled from the nucleotide regulatory protein (see Lefkowitz and Williams, 1978; Rodbell, 1980, for review). Thus, it may be of interest to note that Chuang et al. (1980) have shown that $\beta$ receptors on the cell surface (frog erythrocytes) are sensitive to modulation by GTP, while those which have been internalized (subsequent to desensitization) are insensitive to GTP. Furthermore, Bray et al. (1971) have found that fluoridestimulated adenylate cyclase (which involves the nucleotide regulatory protein (Rodbell, 1980)) accumulates proximal but not distal to ligatures placed around the chick sciatic nerve.

Finally, the nontransported receptors (i.e., the bulk of those along the axon away from ligatures) have a nucleotide sensitivity which is less than that of the anterogradely transported receptors. This result may be due to the presence of endogenous nucleotide. Alternatively, the differential sensitivity might be due to a differing degree of heterogeneity in this receptor population or due to differences in the receptor-modulator coupling.

In summary, if it is assumed that anterogradely transported sites, stationary axonal sites, and retrogradely transported sites represent some sequence in the life cycle of the receptor, then our data could mean that there is progressively less modulation of the receptor by regulatory protein through the processes of transport, insertion, and removal of receptors.

\section{References}

Armett, C. J., and J. M. Ritchie (1961) The action of acetylcholine and some related substances on conduction in mammalian nonmyelinated nerve fibers. J. Physiol. (Lond.) 155: 372384.

Berrie, C. P., N. J. M. Birdsall, A. S. V. Burgen, and E. C. Hulme (1979) Guanine nucleotides modulate muscarinic receptor binding in the heart. Biochem. Biophys. Res. Commun. 87: 1000-1005. 
Birdsall, N. J. M., A. S. V. Burgen, and E. C. Hulme (1978a) Correlation between the binding properties and pharmacological responses of muscarinic receptors. In Cholinergic Mechanisms and Psychopharmacology, D. J. Jenden, ed., pp. 25-33, Plenum Press, New York.

Birdsall, N. J. M., A. S. V. Burgen, and E. C. Hulme (1978b) The binding of agonists to brain muscarinic receptors. Mol. Pharmacol. 14: 723-736.

Bisby, M. A., and V. T. Bulger (1977) Reversal of axonal transport at a nerve crush. J. Neurochem. 29: 313-320.

Bray, J. J., C. M. Kon, and B. Breckenridge (1971) Adenyl cyclase, cyclic nucleotide phosphodiesterase and axoplasmic flow. Brain Res. 26: 385-394.

Brimijoin, S., and M. J. Wiermaa (1978) Rapid orthograde and retrograde axonal transport of acetylcholinesterase as characterized by the stop-flow technique. J. Physiol. (Lond.) 285: 129-142.

Cheng, Y. C., and W. H. Prusoff (1973) Relationship between the inhibition constant $\left(K_{i}\right)$ and the concentration of inhibitor which causes 40 percent inhibition $\left(I_{50}\right)$ of an enzymatic reaction. Biochem. Pharmacol. 22: 3099-3108.

Chuang, D., W. J. Kinnier, L. Farber, and E. Costa (1980) Internalization during beta-adrenergic receptor desensitization in frog erythrocytes. Mol. Pharmacol. 18: 348-355.

Grafstein, B., and D. S. Forman (1980) Intracellular transport in neurons. Physiol. Rev. 60: 1167-1283.

Grafstein, B., and I. G. McQuarrie (1978) Role of the nerve cell body in axonal regeneration. In Neuronal Plasticity, C. W. Cotman, ed., pp. 155-195, Raven Press, New York.

Hancock, J. C., and R. L. Volle (1969) Blockade of conduction in vagal fibers of nicotinic drugs. Arch Int. Pharmacodyn. Ther. 173: 85-95.

Hulme, E. C., N. J. M. Birdsall, A. S. V. Burgen, and P. Mehta (1978) The binding of antagonists to brain muscarinic receptors. Mol. Pharmacol. 14: 737-750.

Jones, S. W., R. T. Galasso, and R. D. O'Brien (1977) Nicotine and alpha-bungarotoxin binding to axonal and non-neural tissues. J. Neurochem. 29: 803-809.

Laduron, P. (1980) Axoplasmic transport of muscarinic receptors. Nature 286: 287-288.

Langer, S. Z. (1977) Presynaptic receptors and their role in the regulation of transmitter release. Br. J. Pharmacol. 60: 481497.

Lefkowitz, R. J., and L. T. Williams (1978) Molecular mechanisms of activation and desensitization of adenylate cyclase coupled beta-adrenergic receptors. Adv. Cyclic Nucleotide Res. 9: 1-17.

McClure, W. O. (1972) Effect of drugs upon axoplasmic transport. Adv. Pharmacol. Chemother. 10: 185-220.

Rodbell, M. (1980) The role of hormone receptors and GTP- regulatory proteins in membrane transduction. Nature 284: 17-22.

Rosenberger, L. B., W. R. Roeske, and H. I. Yamamura (1979) The regulation of muscarinic cholinergic receptors by guanine nucleotides in cardiac tissue. Eur. J. Pharmacol. 56: 179-180.

Rosenberger, L. B., H. I. Yamamura, and W. R. Roeske (1980) Cardiac muscarinic cholinergic receptor binding is regulated by $\mathrm{Na}^{+}$and guanyl nucleotides. J. Biol. Chem. 255: 820-823.

Schwartz, J. H. (1979) Axonal transport: Components, mechanisms and specificity. Annu. Rev. Neurosci. 2: 467-504.

Starke, K. (1977) Regulation of noradrenaline release by presynaptic receptor systems. Rev. Physiol. Biochem. Pharmacol. 77: 1-124.

Szerb, J. C., P. Hadhalzy, and J. D. Dudar (1977) Release of ${ }^{3} \mathrm{H}$-acetylcholine from hippocampal slices: Effect of septal lesion and of graded concentrations of muscarinic agonists and antagonist. Brain Res. 128: 285-291.

Unnerstall, J. R., M. J. Kuhar, D. L. Niehoff, and J. M. Palacios (1981) Benzodiazepine receptors are coupled to a subpopulation of GABA receptors: Evidence from a quantitative autoradiographic study. J. Pharmacol. Exp. Ther. 218: 797804.

Wamsley, J. K., M. A. Zarbin, N. M. J. Birdsall, and M. J. Kuhar (1980) Muscarinic cholinergic receptors: Autoradiographic localization of high and low affinity agonist binding sites. Brain Res. 200: 1-12.

Wamsley, J. K., M. S. Lewis, W. S. Young, III, and M. J. Kuhar (1981a) Autoradiographic localization of muscarinic cholinergic receptors in rat brainstem. J. Neurosci. 1: 176-191.

Wamsley, J. K., M. A. Zarbin, and M. J. Kuhar (1981b) Muscarinic cholinergic receptors flow in the sciatic nerve. Brain Res. 217: 155-162.

Wei, J. W., and P. V. Sulakhe (1979) Agonist-antagonist interactions with rat atrial muscarinic cholinergic receptor sites: Differential regulation by guanine nucleotides. Eur. J. Pharmacol. 58: 91-92.

Westphall, T. C. (1977) Local regulation of adrenergic transmission. Physiol. Rev. 57: 659-728.

Yamamura, H. I., and S. H. Snyder (1974) Muscarinic cholinergic binding in rat brain. Proc. Natl. Acad. Sci. U. S. A. 71: 1725-1729.

Young, W. S., III, and M. J. Kuhar (1979) A new method for receptor autoradiography: $\left[{ }^{3} \mathrm{H}\right]$ Opioid receptors in the rat brain. Brain Res. 179: 255-270.

Young, W. S., III, J. K. Wamsley, M. A. Zarbin, and M. J. Kuhar (1980) Opioid receptors undergo axonal flow. Science 210: 76-78.

Zarbin, M. A., J. K. Wamsley, R. B. Innis, and M. J. Kuhar (1981) Cholecystokinin receptors: Presence and axonal flow in the rat vagus nerve. Life Sci. 29: 697-705. 